\title{
Temporal variability in the demography of the palaemonid prawn Macrobrachium intermedium in two seagrasses
}

\author{
Charles A. Gray* \\ School of Biological Sciences, University of Sydney, 2006, NSW, Australia
}

\begin{abstract}
Spatial and temporal variations in the demography of the palaemonid prawn Macrobrachium intermedium were investigated in Port Hacking, New South Wales, Australia. Populations in 2 adjacent seagrass meadows, Zostera capricorni and Posidonia australis, were sampled monthly over 3 yr (1976 to 1978) using a small beam trawl. For most population variables there were no consistent differences between meadows and both meadows showed similarly variable temporal changes. Neither meadow consistently supported larger populations nor recruited more juveniles. In 1976 abundance was greater in Zostera than Posidonia, the opposite occurred in 1977, whilst there was no difference in 1978. Seasonal and annual changes in abundances were basically similar in both populations and repeated in all 3 yr. Abundances peaked between spring and autumn and were smallest in winter. In both meadows, abundances were greater in 1976 and 1978 than in 1977 . Breeding and recruitment of juveniles occurred throughout the year, although ovigerous females were most abundant in summer/ autumn and juveniles recruited predominantly in late summer/autumn and in spring. At least 2 cohorts of juveniles were produced annually, the spring cohort being the largest. In 1976 and 1978 more juveniles recruited to the Zostera meadow whilst in 1977 more recruited to the Posidonia meadow. There were no consistent differences in the size structures of the 2 populations. During spring, juveniles predominated until summer/autumn when populations consisted of adults and only a few juveniles, after which the numbers of adults declined to virtually disappear by winter. Females grew faster and attained a larger size than males. Most individuals survived at least 15 mo, but longevity was estimated to be up to 2 yr. For most population variables, year-to-year variations within each meadow were as great as differences between the 2 meadows within each year. These variations were most likely due to factors extrinsic to the seagrasses themselves. This study stresses the need for long-term studies to verify the consistency of spatial differences between sites.
\end{abstract}

\section{INTRODUCTION}

Seagrass meadows support diverse and abundant assemblages of macrofauna and provide nursery areas for fish and crustaceans worldwide (Kikuchi 1980, Young 1981, Pollard 1984, Virnstein 1987). Decapod crustaceans form a conspicuous component of the assemblages of macrofauna in seagrasses (Young \& Wadley 1979, Young 1981, Holmquist et al. 1989a). It has been suggested that caridean prawns may play an integral role in determining the structure and dynamics of communities in seagrasses as they often occur in great densities (Kikuchi 1974, Hooks et al. 1976, Heck

\footnotetext{
- Present address: Fisheries Research Institute, NSW Agriculture \& Fisheries, PO Box 21, Cronulla, 2230, NSW, Australia
}

\& Orth 1980, Gore et al. 1981, Young 1981, Howard 1984, Bauer 1985a, Holmquiest et al. 1989a, b), are predators on other seagrass macro- and meiofauna (Nelson 1981a, b, Howard 1984, Leber 1985) and are themselves items of prey for larger prawns, fish and wading birds (Kikuchi 1974, Adams 1976, Bell \& Harmelin-Vivien 1983, Burchmore et al. 1984, Howard 1984, Howard \& Lowe 1984, Leber 1985). Similar roles have been proposed for other prawns in other estuarine/nearshore habitats (Bell \& Coull 1978, Reise 1978, Bell 1980, Evans 1984, Kneib 1984). Despite this potentially important role, there are few studies concerning the population dynamics and life history characteristics of seagrass-dwelling carids, nor of factors which influence their distributions and abundances. Such information is essential in any assessment of the effects of carids on other fauna in seagrasses. 
There are numerous accounts of spatial, diel and seasonal variations in the abundances of carids in seagrasses (Berglund 1980, 1982, Heck \& Orth 1980, Gore et al. 1981, Greening \& Livingston 1982, Heck \& Thoman 1984, Howard 1984, 1987, Bauer 1985a, Emmerson 1986, Gray \& Bell 1986, Holmquist et al. 1989a, b), but studies on their life histories, and how these may vary in space and over time, are restricted to a few species. Such studies include those by Berglund (1980, 1981, 1982, 1984) on Palaemon adspersus, P. serratus and $P$. squilla, Baden \& Pihl (1984) on P. adspersus, Emmerson (1986) on $P$. pacificus and Bauer (1986) on Thor manningi. Bauer (1989) also provides a detailed account of reproduction and recruitment in 9 species of carids, whilst Dugan (1983) provides some data on the demography of 6 species of seagrass-dwelling carids. There have been numerous studies, however, on the demography of carids in other estuarine and nearshore environments (e.g. Hoglund 1943, Alon \& Stancyk 1982, Evans \& Tallmark 1984, Emmerson 1985, Kneib 1987).

The palaemonid prawn Macrobrachium intermedium Stimpson (hereafter Macrobrachium) is one of the most abundant prawns inhabiting estuarine areas and in particular, seagrass meadows, in southeastern Australia (Young 1981, Howard 1984). Its life history has been documented for an estuary in southeastern Tasmania (Walker 1979) and in Western Port, Victoria (Howard 1981, 1984, Howard \& Lowe 1984). Here I report spatial and temporal variations in the abundances, recruitment, reproduction, growth and size structures of populations of Macrobrachium in 2 adjacent meadows of different species of seagrass in Port Hacking (New South Wales, Australia) among different seasons over 3 yr. Previously, Young (1981) documented temporal variability in an assemblage of macrofauna in these meadows and concluded that much variability was unexplained. Much of the variability may have been masked, however, in his multispecies analysis. In this study I provide a detailed analysis of the demography of the most abundant species (Macrobrachium) in Young's study, which may give greater insight into factors influencing the distribution and abundance of organisms in these seagrasses. I compare my findings to those reported previously for Macrobrachium by Walker (1979), Howard (1981, 1984) and Howard \& Lowe (1984) and discuss the demography of Macrobrachium in relation to other prawns in seagrasses and other estuarine and nearshore environments.

\section{MATERIALS AND METHODS}

Study area. Port Hacking $\left(34^{\circ} 04.6^{\prime} \mathrm{S}, 151^{\circ} 06.6^{\prime} \mathrm{E}\right)$, New South Wales, Australia (Fig. 1), is a drowned river valley, with marine conditions except during periods of heavy rainfall. The study area was located on an intertidal sandbank near Costens Point, with adjacent Zostera capricorni Aschers, and Posidonia australis Hook f. meadows. These meadows cover an area of ca $0.69 \mathrm{~km}^{2}$ and are covered by about $1.3 \mathrm{~m}$ of water at high tide. Although the sandbank is intertidal, its basin shape retained a layer of water 10 to $15 \mathrm{~cm}$ deep at low tide.

The Posidonia meadow was $10 \mathrm{~cm}$ deeper than the Zostera meadow, but this difference was much smaller than seasonal and annual variations in depth of water at each site (Fig. 2). Temperatures and salinities of water were similar in both meadows throughout the study (Fig. 2). Maximum temperatures occurred

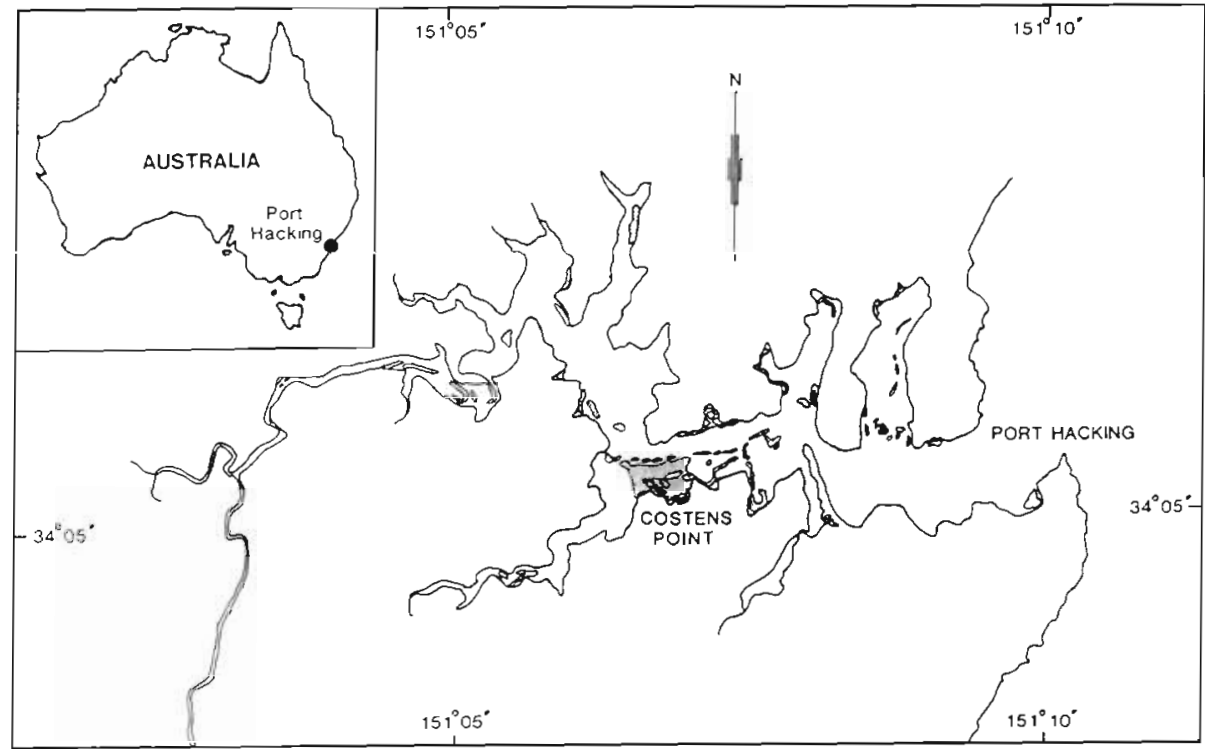

Fig. 1. Seagrass meadows (stippled areas) in Port Hacking and location of study area adjacent to Costens Point 


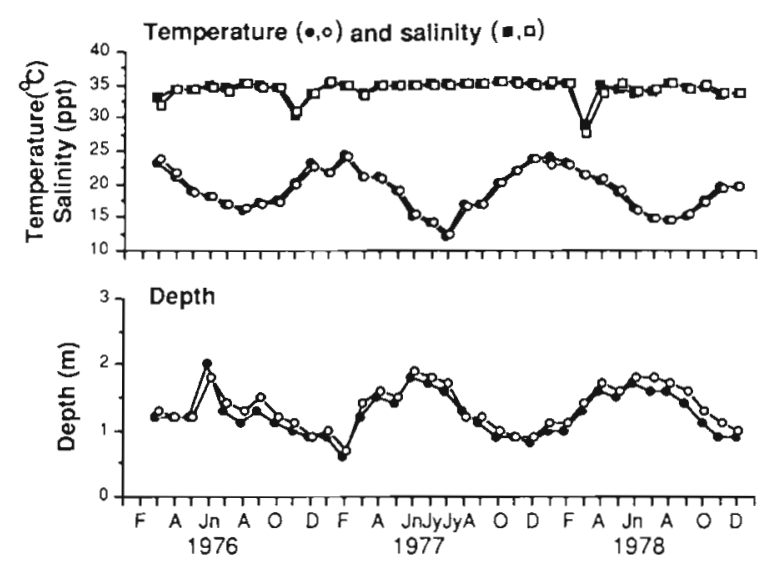

Fig. 2. Depth, temperature and salinity of water at each meadow at Costens Point, 1976 to 1978. In this and all subsequent figures: $(\bullet$, a) Zostera capricorni; $(0, \square)$ Posidonia australis

between December and March whilst minimum temperatures occurred in July or August of each year (Fig. 2). Salinity was fairly consistent throughout the study and showed no annual patterns, although lower salinities were recorded in October 1976 and March 1978 (Fig. 2).

Sampling. Sampling was done as outlined by Young (1981). Sampling was conducted monthly, over a 3 yr period (1976 to 1978), at night on the full moon and within $0.5 \mathrm{~h}$ of high tide. Using a beam trawl, $1 \mathrm{~m}$ wide and $0.5 \mathrm{~m}$ high with $2 \mathrm{~mm}$ mesh in the body and $1 \mathrm{~mm}$ mesh in the cod end of the net, 3 replicate trawls were taken in each meadow on each sampling occasion. Trawls were over a distance of $50 \mathrm{~m}$ on adjacent but non-overlapping strips of seagrass. The beam trawl did not damage the seagrasses, nor did 3 trawls reduce the population sizes of Macrobrachium (Wadley 1980). Prior to trawling, the depth, temperature and salinity of water were recorded at each site. Samples were retained and the number of Macrobrachium in each trawl were recorded.

When possible, 300 Macrobrachium were randomly chosen from each meadow on each sampling occasion and examined in the laboratory. Carapace length (CL; distance from the posterior orbital margin of the eye to the posterior dorsal mid lateral margin of the carapace) was recorded for each prawn. Measurements were made to the nearest $0.1 \mathrm{~mm}$ using a binocular microscope with an ocular micrometer. The sex of each individual was recorded and the number of ovigerous females noted. Sex could not be accurately determined for specimens $<3.1 \mathrm{~mm} \mathrm{CL}$ and so individuals below this size were considered as 'juvenile'.

\section{RESULTS}

\section{Variations in abundances}

Relative abundances of Macrobrachium differed significantly between sites and this differed among seasons (significant interaction in ANOVA; Table 1). Neither site consistently had greater or lesser abundances in any season. In all seasons except winter, abundances were greater in Zostera than in Posidonia in 1976, the opposite occurred in 1977, and there was no significant difference in 1978 (Fig. 3). Despite the significant site $\times$ season interaction, abundances at both sites experienced similar temporal changes throughout the study. In all 3 yr, smallest abundances occurred in winter (July), but there was no consistent seasonal pattern at either site with respect to greatest abundances (SNK tests based on data in Fig. 3). Periods of greatest abundances usually occurred from summer to autumn (November to March). Months also differed within seasons, although the non-significant site $\times$ months interaction indicated that such effects were similar at both sites. Abundances at each site differed among similar seasons in different years (SNK tests based on data in Fig. 3), although annual variations were similar at both sites. At both sites abundances were greater in 1976 and 1978 than in 1977 . Annual variations in abundances at each site were

Table 1. Macrobrachium intermedium. Summaries of 3 -factor analyses of variance of population variables over 11 seasons between March 1976 and November 1978. Data transformed by ${ }^{a} \ln (x),{ }^{b} \ln (x+1)$ to stabilise variances. Cochran's tests after transformations $\mathrm{p}>0.05 . \cdot \mathrm{p}<0.05, \cdots p<0.01, \cdots p<0.001$; ns: non-significant, $p>0.05$

\begin{tabular}{|lrccc|}
\hline Source of variation & df & $\begin{array}{c}\text { Totai } \\
\text { abundance }\end{array}$ & $\begin{array}{c}\text { No. of ovigerous } \\
\text { females }\end{array}$ & $\begin{array}{c}\text { Percentage of } \\
\text { ovigerous females }^{b}\end{array}$ \\
\hline Site & 1 & $\ldots$ & $\ldots$ & $\ldots$ \\
Season & 10 & $\ldots$ & $\ldots$ & ns \\
Site $\times$ Season & 10 & $\ldots$ & $\ldots$ & $\cdots$ \\
Month (Season) & 22 & $\ldots$ & ns & ns \\
Site $\times$ Month (Season) & 22 & ns & & \\
Residual & 132 & & & \\
\hline
\end{tabular}



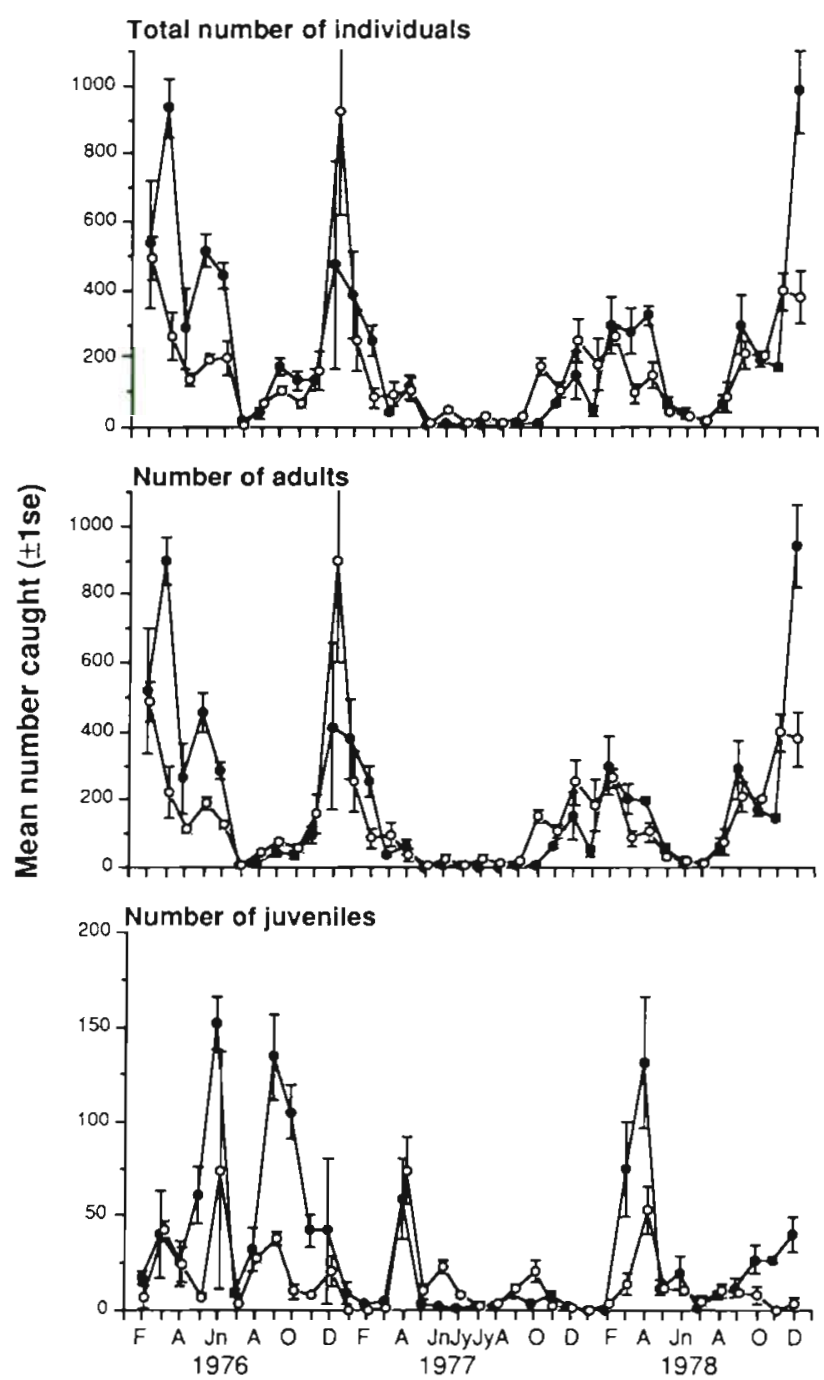

Fig. 3. Macrobrachium intermedium. Mean total number, number of adults and number of juveniles caught in each meadow, 1976 to 1978. Symbols as in Fig. 2

greater than variations in abundances between sites within each year.

\section{Recruitment of juveniles}

Some recruitment of juveniles occurred at both sites throughout each year, although the number of juveniles caught varied between sites and among seasons (Fig. 3). No statistical analysis on this data was done due to heteroscedasticity of the variances. Nonetheless, there appeared to be no consistent pattern across years as to which site recruited most juveniles. In 1976 and 1978 juveniles were generally more abundant in the Zostera meadow, whereas in 1977 they were more abundant in the Posidonia meadow (Fig. 3). Temporal changes in the number of juveniles caught were gener- ally similar at both sites and repeated in all $3 \mathrm{yr}$. In each year, abundances of juveniles peaked in autumn (February to June), then decreased until late winter/spring (August to September), when a second (usually smaller) peak occurred. This was followed by decreases in abundances until autumn (Fig. 3). The timing of peak periods of recruitment were generally similar at both sites in each year, but varied among years. Abundances of juveniles during each peak period varied between sites within each year and at each site among years (Fig. 3). In each year, except in the Zostera meadow in 1976, the autumn peak in recruitment appeared the larger (Fig. 3).

Despite some recruitment in all months, analyses of size frequency data (see 'Growth' below) showed that 2 distinct juvenile cohorts occurred each year (Fig. 4). In all $3 \mathrm{yr}$ the first cohort appeared in late summer/ autumn (February/March) and the second in late autumn to spring (April/May to October). In 1976, the first juvenile cohort was clearly evident in the Zostera meadow in February and in the Posidonia meadow in March (Fig. 4). The second cohort first appeared in the Zostera meadow in May and in the Posidonia meadow in June (Fig. 4). In 1978 a third cohort appeared in spring (September) in the Zostera meadow.

\section{Breeding}

The smallest sized ovigerous female Macrobrachium caught was $5.1 \mathrm{~mm}$ CL. The size and time that females first became ovigerous was the same in both meadows and in all $3 \mathrm{yr}$. Some females from the first cohort recruited each year (summer/autumn) became ovigerous in late spring, whereas some from the second cohort (autumn/spring) were ovigerous in early summer. This occurred at a size of 5.0 to $5.4 \mathrm{~mm} \mathrm{CL}$. The majority of females, however, were not ovigerous until 5.8 to $6.0 \mathrm{~mm}$ CL in late summer/autumn (see Fig. 4 for an example of 1976).

Both the abundances of ovigerous females and the percentage of all females that were ovigerous were analysed to determine patterns of breeding. The timing and intensity of peaks in abundances of ovigerous females varied significantly between sites in each year and among years (ANOVA; Table $1 ;$ Fig. 5). Ovigerous females were caught in all months of the study except May 1977 (Fig.5), although they were generally more abundant in summer (November to March) in all years (SNK tests based on data in Fig. 5). The patterns of temporal change in abundances of ovigerous females were similar to those for abundances of the total populations. Neither meadow consistently had the greatest number of ovigerous females in autumn or winter. although in spring and summer in all years they were 

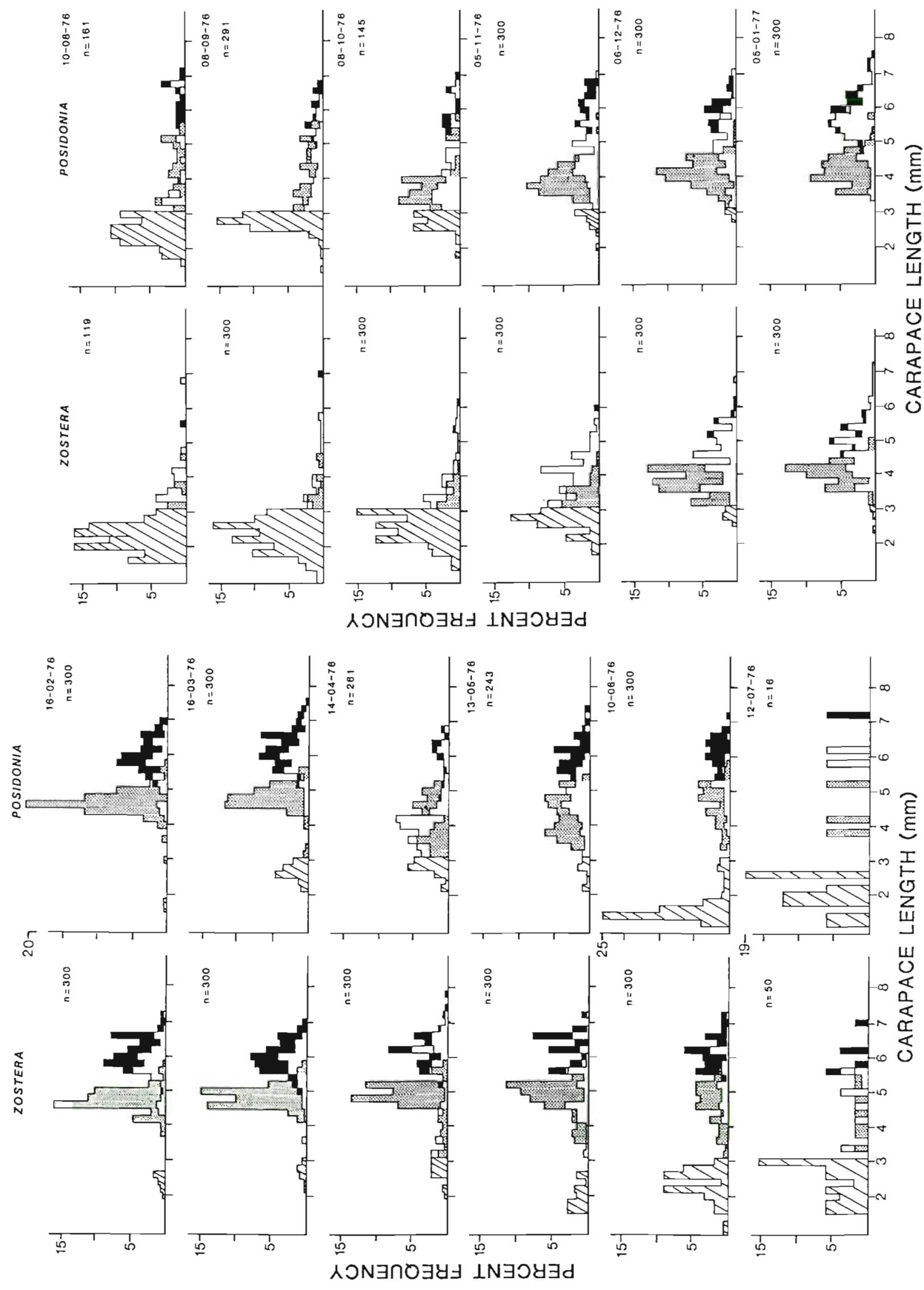

$\circ \quad 1 \quad$

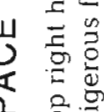

0
$\frac{0}{0}$
0
0
0
0
0
0
0
0
0

$\Xi \ddot{i}$

욜 

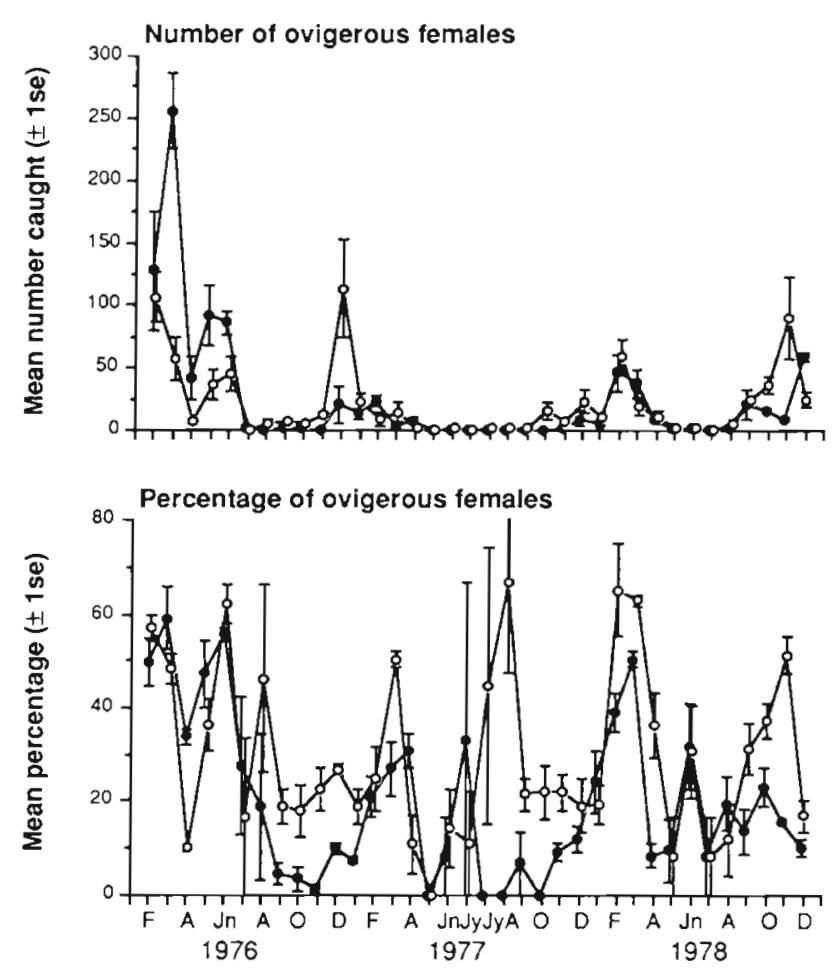

Fig. 5. Macrobrachium intermedium. Mean number of ovigerous females and mean percentage of ovigerous females in the total female populations caught in each meadow, 1976 to 1978. Symbols as in Fig. 2

more abundant in the Posidonia meadow (SNK tests based on data in Fig. 5). The percentage of all females that were ovigerous also varied between sites and this differed among seasons (significant interaction in ANOVA; Table 1), but trends were different and more variable than changes in abundances of ovigerous females (Fig. 5). There was no pattern among years, for either site, as to the season in which the greatest or least percentages occurred. Periods of peak percentages of ovigerous females usually occurred, however, in late summer/autumn, while troughs occurred in winter/ spring of most years. As for abundances of ovigerous females, the percentage of ovigerous females was greater in Posidonia in spring and summer whilst in autumn and winter there was no difference between meadows.

In both populations there was a progressive change in the size of ovigerous females throughout each year. In spring, ovigerous females were mainly large (Fig. 4) and came from the overwintering population. Over late spring/summer the mean size of ovigerous females decreased as females from that year's recruitment spawned for the first time, and the numbers of overwintering prawns declined. Throughout late summer/ autumn the mean size of ovigerous females increased as the first-time spawners grew (Fig. 4). This pattern was generally repeated in all 3 years.

\section{Size structures of populations}

There were no consistent differences in the size structures of the 2 populations, despite the number of cohorts present and their relative predominance varying. There was an annual pattern of change in size structures similar to both populations and generally repeated in all $3 \mathrm{yr}$. When the populations were first sampled in February 1976 they were bimodal, representing separate male and female size groups (Fig. 4). From this time until June 1976 the large male and female size classes gradually disappeared, whilst 2 juvenile size groups appeared and subsequently increased in size. The first juvenile cohort appeared in February/March (late summer) and the second in April/May (autumn) (Fig. 4). During this time, size distributions became polymodal. By August 1976 the populations consisted mainly of juveniles and a few individuals of most of the other size groups. Throughout September to November (spring), size distributions remained polymodal, due to the presence of at least 2 male and 2 female size groups and a juvenile size group at each site. The populations remained this way until January/February 1977, when the smaller and larger size groups merged to form a single male size group and 2 female size groups (Fig. 4). From February to April 1977 the larger male and female size classes gradually disappeared and a new juvenile size class appeared, as in the same period in 1976. Due to low densities there was no clear pattern until September/October 1977. Populations at this time were polymodal and similar to those at the same time in 1976. Changes in the size structures of the populations until the end of 1978 were similar to those described for 1976/77 (Gray 1985).

\section{Growth}

Growth of Macrobrachium was estimated from the monthly size frequency data. Individual cohorts of different mean sizes were extracted for each month using probability paper (Cassie 1954) and plotted against time. Due to the long recruitment periods and merging of size groups, it was difficult to obtain discrete size cohorts from the data. Some size groups were bimodal, although they could not be separated reliably by the analysis.

Although variable, changes in the mean sizes of cohorts were similar in both populations in all $3 \mathrm{yr}$. Females grew faster and attained a larger size than males (Fig. 6). Growth in the cohorts of juveniles was usually quite rapid, about $0.5 \mathrm{~mm} \mathrm{CL} \mathrm{mo}^{-1}$. Sometimes in winter/spring, however, little growth occurred (e.g. Zostera 1976), presumably due to continual recruitment keeping mean sizes low. Male and female cohorts increased at about $0.5 \mathrm{~mm} \mathrm{CL} \mathrm{mo}^{-1}$ and 


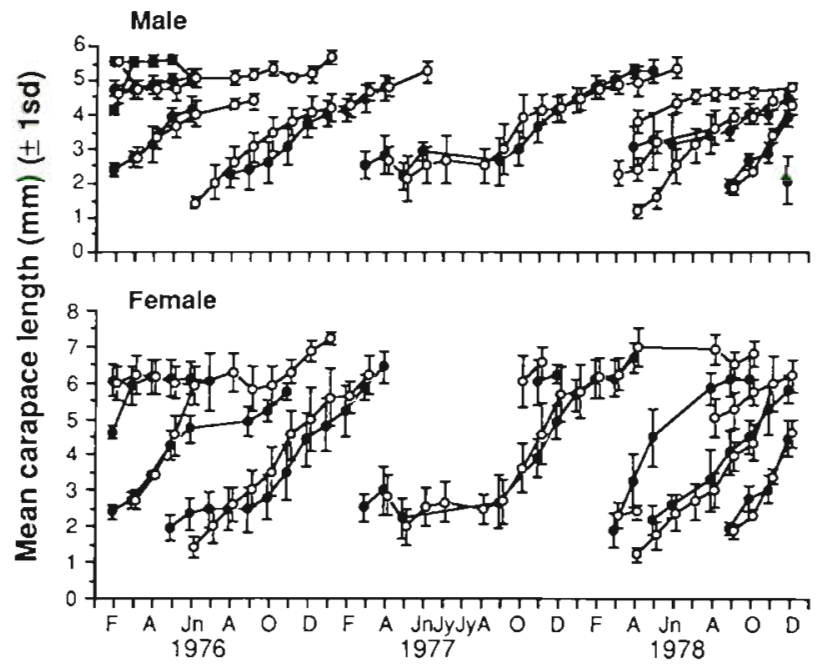

Fig. 6. Macrobrachium intermedium. Mean carapace lengths of male and female cohorts in each meadow, 1976 to 1978. Symbols as in Fig. 2

$0.7 \mathrm{~mm} \mathrm{mo}^{-1}$, respectively, but these rates decreased as cohorts reached their mean maximum sizes (Fig. 6). Mean maximum sizes of cohorts were similar in both meadows in all $3 \mathrm{yr}$; males about $4.8 \mathrm{~mm} \mathrm{CL}$; females about $6.0 \mathrm{~mm} \mathrm{CL}$. The largest individuals caught were $6.6 \mathrm{~mm} \mathrm{CL}$ (males) and $9.2 \mathrm{~mm} \mathrm{CL}$ (females). Differences in the rate of growth in different seasons were not determined because these were masked by prawns being different sizes in each season, low sample sizes during winter and continual recruitment throughout spring.

Longevity for Macrobrachium in Port Hacking was estimated to be up to 2 yr for females and 1.5 yr for males, but most individuals did not appear to live past 15 mo.

\section{DISCUSSION}

\section{Spatial and temporal variations in abundances}

The data from this study suggests that species of seagrass had no effect on the abundances, or on any other demographic variable, of Macrobrachium. Neither meadow consistently supported the largest population, nor recruited greater numbers of juveniles. Previous studies have attributed differences in the abundances of organisms in different seagrasses to quantitative and qualitative differences in the seagrasses (Kikuchi \& Peres 1977, Stoner 1980, 1983a, b, Martin \& Cooper 1981, Lewis 1984, Middleton et al. 1984, Bell \& Westoby 1986). Variations in the abundances of Macrobrachium between the Zostera and Posidonia meadows described in this study were probably not attributable, however, to morphological differ- ences between the seagrasses. Gray 1991 (companion paper) found that there were no consistent differences in the abundances of Macrobrachium in Zostera and Posidonia meadows at several other localities in 1983 and 1984. It was also unlikely that differences in abundances between sites were caused by differing environmental factors, as these meadows were adjacent and influenced by similar water temperatures and salinities. Likewise, the difference in the depth of water between the 2 sites was also unlikely to have caused the variations in abundances of Macrobrachium between the 2 meadows. The difference in depth was the same across all $3 \mathrm{yr}$, whereas differences in abundances between the 2 meadows changed among years. Nonetheless, depth of water has been shown to affect the distribution and abundance of other prawns in seagrasses (Young \& Carpenter 1977, Baden \& Pihl 1984, Emmerson 1986; see Gray 1991). It was most likely that the spatial variability in the abundances of Macrobrachium between the 2 meadows was due to factors extrinsic to the 2 sites themselves, namely variable recruitment, as proposed for the whole vagile assemblage by Young (1981).

The general seasonal pattern of abundance of Macrobrachium in Port Hacking differed slightly from those found by Walker $(1979)$ and Howard $(1981,1984)$ for populations in higher latitudes in southeastern Australia, where minimum abundances usually occurred during spring. The period of greatest abundance, however, was similar in all studies. Gray (1991), on the other hand, showed that the general seasonal pattern of abundance of Macrobrachium at several localities in other estuaries in the Sydney region was the same as that found in this study. Although the mechanism(s) causing the autumn/winter decreases in abundances of Macrobrachium in Port Hacking (and in other nearby estuaries; see Gray 1991) are not known, I hypothesise that Macrobrachium temporarily move away from the seagrasses into deeper water in winter. Other methods used to catch seagrass fauna (e.g. poisoning and coring) also caught fewer Macrobrachium in winter than at other times (Gray unpubl.), and Macrobrachium has been caught down to depths of $35 \mathrm{~m}$ (Walker 1979). During late winter/spring some individuals re-colonize the seagrasses; only a few of the largest sized prawns return, the majority being recruiting juveniles. Similar seasonal depth migrations and overwintering in deeper waters have been reported for other estuarine/nearshore palaemonid prawns (Hogland 1943, Forster 1951, Nixon \& Oviatt 1973, Baden \& Pihl 1984, Emmerson 1986). There have been, however, only a few reported seasonal movements of seagrass-associated caridean prawns (Kikuchi 1974, Howard 1984, Emmerson 1986), presumably as most are reported resident species. Many of the species that are reported to be permanent 
residents may, in fact, move among habitats. Further research is needed to assess this. In contrast, there have been numerous reports of seasonal movements of several species of penaeid prawns which inhabit seagrasses only as juveniles (Young 1978, Bauer 1985b, Staples et al. 1985).

Year-to-year variations in the seasonal abundances of Macrobrachium in each meadow were generally greater than variations between the 2 meadows within each year. This emphasises the need to consider the consistency of spatial variations between sites over periods greater than 1 yr. Annual variations in abundances were, however, similar at both sites, which may reflect the closeness of sites and similar recruitment events. Low abundance and little recruitment for many species of macrofauna occurred in these meadows in 1977, but not for all species of carids (Young 1981).

\section{Demographic patterns}

Some breeding and recruitment took place year round at both sites, which differed from the results obtained by Walker (1979) and Howard (1981). They found that ovigerous females and juveniles were only present between spring and autumn, when they were most abundant in this study. Latitudinal differences in the length of periods of breeding have been recorded for many marine organisms, including palaemonid prawns (Alon \& Stancyk 1982, Berglund 1984), and have usually been attributed to differing temperatures of water. Generally, periods of breeding and recruitment are reduced in higher latitudes. Year-round breeding and recruitment has been observed, however, in other temperate and tropical seagrass-associated carids (Heck 1977, Dugan 1983, Emmerson 1986, Bauer 1989). Female Macrobrachium are capable of breeding at least 2 or 3 times in one breeding season (Walker 1979, Gray unpubl.), and may be capable of continuous breeding thereafter, similar to other palaemonid prawns (Bauer 1989)

In spring and summer in all $3 y r$, ovigerous female Macrobrachium were more abundant in the Posidonia meadow, which may have been due to this meadow occurring on the outer edge of the sand bank. Gray (1991), however, found that this did not always occur in these same meadows in 1983/1984, nor did it occur at other places in nearby estuaries. Nevertheless, the abundance of ovigerous females in spring primarily depends on the number of overwintering females, and hence females immigrating from deeper water would come across the Posidonia meadow before the Zostera meadow. Other ovigerous female palaemonids migrate into deeper water, usually leaving estuaries, to spawn (Baden \& Pihl 1984, Emmerson 1986), but there are no reports of females moving back into shallower water. The gradual seasonal changes in the sizes of ovigerous females throughout each year were similar to those found in other prawn populations which are characterised by 2 reproductive and recruitment periods a year (Hoglund 1943, Alon \& Stancyk 1982, Baden \& Pihl 1984, Evans \& Tallmark 1984).

There was no consistent pattern as to which meadow received more juvenile recruits. Variations in the magnitude of recruitment between the Zostera and Posidonia meadow in each year were as great as the year-to-year variations in recruitment in each meadow. These variations most likely reflect differences in the numbers of recruits at settlement or variations in post-settlement mortality. Gray (1991) showed that there was no effect of species of seagrass on the number of juvenile Macrobrachium caught in other seagrass meadows in nearby estuaries. Despite the variations in the timing and magnitude of recruitment between sites and among years, the number of juvenile cohorts produced each year was similar to both meadows and was generally repeated in all 3 yr. At least. 2 distinct size/age cohorts were produced each year; the first (summer/autumn recruits) probably originated from the overwintering prawns that spawned in late spring/summer the previous year and the second (autumn/spring recruits) from the summer/ autumn spawners. This pattern of recruitment and production of cohorts differed to that found by Walker (1979) and Howard (1981), but is similar to many other species (carids and penaeids) of prawns (Hoglund 1943, Young 1978, Kennedy \& Barber 1981, Alon \& Stancyk 1982, Baden \& Pihl 1984, Evans \& Tallmark 1984, Rothlisberg et al. 1985, Emmerson 1986). Walker (1979), Howard (1981) and Howard \& Lowe (1984) found that juveniles were only present between spring and autumn with only one peak, usually in midsummer, producing a single cohort. Howard (1981) also reported that larvae of Macrobrachium were only present during those periods. Similar intraspecific latitudinal differences in the patterns of reproduction and recruitment have been reported among populations of other prawns (Beck \& Cowell 1976. Alon \& Stancyk 1982, Berglund 1984, Rothlisberg et al. 1985).

Female Macrobrachium in Port Hacking grew faster and reached a greater mean and maximum CL (and overall length) than males, as found by Walker (1979) and Howard (1981), and also found for other palaemonid prawns (Hoglund 1943, Forster 1951, Beck \& Cowell 1976, Truesdale \& Mermillioud 1979, Berglund 1981, Alon \& Stancyk 1982, Emmerson 1986). Only in some freshwater species of Macrobrachium have males been found to attain a larger size than females (Ling 1969, Koshy 1971, Guest 1979). 
Estimates of longevity for Macrobrachium vary between 1.5 yr (Walker 1979) and 2 yr (Howard 1981, this study). Estimates of longevity of other estuarine/ marine palaemonid prawns also vary between 1 to 1.5 yr (Palaemonetes pugio; Alon \& Stancyk 1982), and 2 to 3 yr (Palaemon squilla, P. elegans, P. adspersus, P. pacificus; Hogland 1943, Forster 1951, Baden \& Pihl 1984, Emmerson 1986).

This study shows that the differences in the demography of Macrobrachium between the 2 sites sampled varied from year to year. These differences between the 2 populations were unique to each year. If this study had been done over $1 \mathrm{yr}$, the results and conclusions would have totally differed. This emphasises the need to consider the consistency among years of variations in demography between populations. The variability in demography both within and between the 2 populations of Macrobrachium in Port Hacking was as great as those found for other palaemonid prawns over larger spatial scales (between sites in different estuaries) in other studies (Alon \& Stancyk 1982, Emmerson 1986). Clearly, there is a need for future research to investigate spatial variations in demography of these prawns over various scales.

Acknowledgements. I thank V Wadley and P. Young of the Division of Fisheries, C.S.I.R.O., for use of their sample collection. D. Anderson and A. Underwood are thanked for discussions on the work and S. Kennelly, J. Bell and an anonymous referee made useful comments on the manuscript.

\section{LITERATURE CITED}

Adams, S. M. (1976). Feeding ecology of eelgrass fish communities. Trans. Am. Fish Soc. 105: 514-519

Alon, N. C., Stancyk, S. E. (1982). Variation in life-history patterns of the grass shrimp Palaemonetes pugio in two South Carolina estuarine systems. Mar. Biol. 68: 265-276

Baden, S. P., Pihi, L. (1984). Abundance, biomass and production of mobile epibenthic fauna in Zostera marina (L.) meadows, western Sweden. Ophelia 23: 65-90

Bauer, R. T. (1985a). Diel and seasonal variation in species composition and abundance of caridean shrimps (Crustacea, Decapoda) from seagrass meadows on the north coast of Puerto Rico. Bull. mar Sci. 36: 150-162

Bauer, R. T. (1985b). Penaeoid shrimp fauna from tropical seagrass meadows: species composition, diurnal, and seasonal variation in abundance. Proc. Biol. Soc. Wash. 98: $177-190$

Bauer, R. T (1986). Sex change and life history pattern in the shrimp Thor manningi (Decapoda: Caridea): a novel case of partial protandric hermaphroditism. Biol. Bull. mar. biol. Lab., Woods Hole 170: 11-31

Bauer, R. T. (1989). Continuous reproduction and episodic recruitment in nine shrimp species inhabiting a tropical seagrass meadow. J. exp. mar Biol. Ecol. 127: 175-187

Beck, J. T., Cowell, B. C. (1976). Life history and ecology of the freshwater caridean shrimp, Palaemonetes paludosus (Gibbes). Am. Midl. Nat. 96: 52-65
Bell, J. D., Harmelin-Vivien, M. L. (1983). Fish fauna of French Mediterranean Posidonia oceanica seagrass meadows. 2. Feeding habits. Tethys 11 1-14

Bell, J. D., Westoby, M. (1986). Importance of local changes in leaf height and density to fish and decapods associated with seagrasses. J. exp. mar Biol. Ecol. 104: 249-274

Bell, S. S. (1980). Mejofauna-macrofauna interactions in a high salt marsh habitat. Ecol. Monogr. 50: 487-505

Bell, S. S., Coull, B. C. (1978). Field evidence that shrimp predation regulates meiofauna. Oecologia (Berl.) 35: $141-148$

Berglund, A. (1980). Niche differentiation between two littoral prawns in Gullmar Fjord, Sweden: Palaemon adspersus and P. squilla. Holarctic Ecol. 3: 111-115

Berglund, A. (1981). Sex dimorphism and skewed sex ratios in the prawn species Palaemon adspersus and $P$. squilla. Oikos 36: 158-162

Berglund, A. (1982). Coexistence, size overlap and population regulation in tidal vs non-tidal Palaemon prawns. Oecologia (Berl.) $54: 1-7$

Berglund, A. (1984). Reproductive adaptations in two Palaemon prawn species with differing habitat requirements. Mar. Ecol. Prog. Ser. 17: 77-83

Burchmore, J. J., Pollard, D. A., Bell, J. D. (1984). Community structure and trophic relationships of the fish fauna of an estuarine Posidonia australis seagrass habitat in Port Hacking, New South Wales. Aquat. Bot. 18: 71-87

Cassie, R. M. (1954). Some uses of probability paper in the analysis of polymodal size distributions. Aust. J. mar. Freshwat. Res. 5: 513-522

Dugan, P. J. (1983). Seasonal and geographic distribution of seven decapod crustaceans in Apalachee Bay, Florida Contr mar Sci. 26: 65-79

Emmerson, W. D. (1985). Seasonal abundance, growth and production of Palaemon pacificus (Stimson) in eastern Cape tidal pools. S. Afr. J. Zool. 20: 221-231

Emmerson, W. D. (1986). The ecology of Palaemon pacificus (Stimpson) associated with Zostera capensis. Trans. R. Soc. S. Afr. 46: 79-97

Evans, S. (1984). Energy budgets and predation impact of dominant epibenthic carnivores on a shallow, soft bottom community at the Swedish west coast. Estuar. coast. Shelf Sci. 18: 651-672

Evans, S., Tallmark, B. (1984). Seasonal dynamics of small vagile predators on a marine shallow soft bottom. Holarctic Ecol. 7: 138-148

Forster, G. R. (1951). The biology of the common prawn, Leander serratus Pennant. J. mar. biol. Ass. U.K. 30 : $333-360$

Gore, R. H., Gallaher, E. E., Scotto, L. E., Wilson, K. A. (1981). Studies on decapod crustacea from the Indian river region of Florida. XI. Community composition, structure, biomass and species areal relationships of seagrass and drift algaeassociated macrocrustaceans. Estuar. coast. Shelf Sci. 12: $485-508$

Gray, C. A. (1985). Seasonal dynamics and life history of the palaemonid shrimp Macrobrachium intermedium in seagrass meadows in the Sydney region. M.Sc. thesis, University of Sydney

Gray, C. A. (1991). Demographic patterns of the palaemonid prawn Macrobrachium intermedium in southeastern Australia: spatial heterogeneity and the effects of species of seagrass. Mar Ecol. Prog. Ser. 75: 239-249

Gray, C. A., Bell, J. D. (1986). Consequences of two common techniques for sampling vagile macrofauna associated with the seagrass Zostera capricorni. Mar. Ecol. Prog. Ser. 28: $43-48$ 
Greening, H. S., Livingston, R. J. (1982). Diel variation in the structure of seagrass associated epibenthic macroinvertebrate communities. Mar. Ecol. Prog. Ser. 7: 147-156

Guest, W. W. (1979). Laboratory life history of the palaemonid shrimp Macrobrachium amazonicum (Heller) (Decapoda, Palaemonidae). Crustaceana 30: 141-152

Heck, K. L. Jr (1977). Comparative species richness, composition and abundance of invertebrates in Caribbean seagrass (Thalassia testudinum) meadows (Panama). Mar Biol. 41: 335-348

Heck, K. L., Jr, Orth, R. J. (1980). Structural components of eelgrass (Zostera marina) meadows in the lower Chesapeake Bay - decapod crustacea. Estuaries 3 289-295

Heck, K. L., Jr, Thomann, T. A. (1984). The nursery role of seagrass meadows in the upper and lower reaches of the Chesapeake Bay. Estuaries 7: 70-92

Hoglund, $H$. (1943). On the biology and larval development of Leander squilla (L.) forma typica De Man. Svenska hydrogr.-biol. Kommn. Skr. Ny Ser, Biol. II: 1-44

Holmquist, J. G., Powell, G. V. N., Sogard, S. M. (1989a) Decapod and stomatopod assemblages on a system of seagrass-covered mud banks in Florida Bay. Mar. Biol 100: $473-483$

Holmquist, J. G., Powell, G. V. N., Sogard, S. M. (1989b) Decapod and stomatopod communities of seagrasscovered mud banks in Florida Bay: inter-and intra-bank heterogeneity with special reference to isolated subenvironments. Bull. mar. Sci. 44: 251-262

Hooks, T A., Heck, K. L. Jr, Livingston, R. J. (1976). An inshore marine invertebrate community: structure and habitat associations in the northeastern Gulf of Mexico. Bull. mar. Sci. 26: 99-109

Howard, R. K. (1981). The ecology and trophic role of caridean shrimps in the eelgrass community of Western Port, Victoria. Ph.D. thesis, University of Melbourne

Howard, R. K. (1984). The trophic ecology of caridean shrimps in an eelgrass community. Aquat. Bot. 18: 155-174

Howard, R. K. (1987). Diel variation in the abundance of epifauna associated with seagrasses of the Indian River, Florida, USA. Mar. Biol, 96: 137-142

Howard, R. K., Lowe, K. W. (1984). Predation by birds as a factor influencing the demography of an intertidal shrimp. J. exp. mar. Biol. Ecol. 74: 35-52

Kennedy, F. S., Jr, Barber, D. G. (1981). Spawning and recruitment of pink shrimp Penaeus duorarum, off eastern Florida. J. crust. Biol. 1: 474-485

Kikuchi, T (1974). Japanese contributions on consumer ecology in eelgrass (Zostera marina L.) beds, with special reference to trophic relationships and resources in inshore fisheries. Aquaculture 4: 145-160

Kikuchi, T (1980). Faunal relationships in temperate seagrass beds. In: Phillips, R. C., McRoy, C. P. (eds.) Handbook of seagrass biology: an ecosystem perspective. Garland STPM Press, New York, p. 153-172

Kikuchi, T., Peres, J. M. (1977). Consumer ecology of seagrass beds. In: McRoy, C. P., Helfferich, C. (eds.) Seagrass ecosystems: a scientific perspective. Marcell Dekker Inc, New York, p. 147-193

Kneib, R. T (1984). Patterns of invertebrate distribution and abundance in the intertidal salt marsh: causes and questions. Estuaries 7: 392-412

Kneib, R. T (1987). Seasonal abundance, distribution and growth of postlarval and juvenile grass shrimp (Palaemonetes pugio) in a Georgia, USA, salt marsh. Mar. Biol. 96: 215-223

Koshy, M. (1971). Studies on the sexual dimorphism in the freshwater prawn Macrobrachium dayanum (Henderson, 1893) (Decapoda, Caridea). Part I. Crustaceana 21 72-78

Leber, K. M. (1985). The influence of predatory decapods, refuge, and microhabitat selection on seagrass communities. Ecology 66: 1951-1964

Lewis III, F. G. (1984). Distribution of macrobenthic crustaceans associated with Thalassia, Halodule and bare sand substrata. Mar. Ecol. Prog. Ser. 19: 101-113

Ling, S. W. (1969). The general biology and development of Macrobrachium rosenbergij (De Man). F.A.O. Fish. Rep. 57: $589-606$

Martin, F. D., Cooper, M. (1981). A comparison of fish faunas found in pure stands of two tropical Atlantic seagrasses, Thalassia testudinum and Syringodium tiliforme. Northeast Gulf Sci. 5: 31-37

Middleton, M. J., Bell, J. D., Burchmore, J. J., Pollard, D. A. Pease, B. C. (1984). Structural differences in the fish communities of Zostera capricorni and Posidonia australis seagrass meadows in Botany Bay, New South Wales. Aquat. Bot. 18: 89-109

Nelson, W. G. (1981a). Experimental studies of decapod and fish predation on seagrass macrobenthos. Mar. Ecol. Prog. Ser. 5: 141-149

Nelson, W. G. (1981b). The role of predation by decapod crustaceans in seagrass ecosystems. Kieler Meeresforsch. Sonderh. 5: 529-536

Nixon, S. W., Oviatt, C. A. (1973). Ecology of a New England salt marsh. Ecol. Monogr. 43: 463-498

Pollard, D. A. (1984). A review of ecological studies on seagrass fish communities, with particular reference to recent studies in Australia. Aquat. Bot. 18: 3-42

Reise, K. (1978). Experiments on epibenthic predation in the Wadden sea. Helgoländer wiss. Meeresunters. 31: $55-101$

Rothlisberg, P. C., Staples, D. J., Crocos, P. J. (1985). A review of the life history of the banana prawn Penaeus merguiensis in the Gulf of Carpentaria. In: Rothlisberg, P. C., Hill, B. J., Staples, D. J. (eds.) Second Aust. Nat. Prawn Sem. NPS2, Cleveland, Australia, p. 125-136

Staples, D. J., Vance, D. J., Heales, D. J. (1985). Habitat requirements of juvenile penaeid prawns and their relationship to offshore fisheries. In: Rothlisberg, P. C., Hill, B. J., Staples, D. J. (eds.) Second Aust. Nat. Prawn Sem. NPS2, Cleveland, Australia, p. 47-54

Stoner, A. W. (1980). Abundance, reproductive seasonality and habitat preferences of amphipod crustaceans in seagrass meadows of Apalachee Bay, Florida. Contr. mar. Sci. 23: $63-77$

Stoner, A. W (1983a). Distributional ecology of amphipods and tanaidaceans associated with three seagrass species. J crust. Biol. 3: 505-518

Stoner, A. W. (1983b). Distribution of fishes in seagrass meadows: role of macrophyte biomass and species composition. Fish. Bull. U.S. 81: $837-846$

Truesdale, F. M., Mermillioud, W. J. (1979). The river shrimp, Macrobrachium ohione (Smith) (Decapoda, Palaemonidae): its abundance, reproduction and growth in the Atchafalaya river basin of Louisana, U.S.A. Crustaceana 36 : $61-73$

Virnstein, R. W. (1987). Seagrass-associated invertebrate communities of the southeastern U.S.A.: a review. Fla mar. Res. Publs. 42: 89-116

Wadley, V A. (1980). Spatial and temporal heterogeneity in the epibenthic fauna of estuarine sand and seagrass beds M.Sc. thesis, University of Sydney

Walker, T. M. (1979). A study of sympatry in two species of Palaemonidae. Ph.D thesis, University of Tasmania 
Young, P. C. (1978). Morton Bay, Queensland: a nursery area for juvenile penaeid prawns. Aust. J. mar. Freshwat. Res. 29: $55-75$

Young, P. C. (1981). Temporal changes in the vagile epibenthic fauna of two seagrass meadows (Zostera capricorni and Posidonia australia). Mar. Ecol. Prog. Ser. 5: 91-102

This article was presented by A. J. Underwood, Sydney, Australia
Young, P. C., Carpenter, S. M. (1977). Recruitment of postlarval penaeid prawns to nursery areas in Moreton Bay, Queensland. Aust. J. mar. Freshwat. Res. 28, 745-773

Young, P. C., Wadley, V. A. (1979). Distribution of shallowwater epibenthic macrofauna in Moreton Bay, Queensland, Australia. Mar Biol. 53: 83-97

Manuscript first received: August 28, 1989

Revised version accepted: June 3, 1991 